\title{
Hemodynamic effects of ropivacaine and levobupivacaine intravenous injection in swines ${ }^{1}$
}

\author{
Efeitos hemodinâmicos da injeção endovenosa de ropivacaína e levobupivacaína em suínos
}

\author{
Artur Udelsmann', William Adalberto Silva"I, Ana Cristina de Moraes ${ }^{\mathrm{II}}$, Elisabeth Dreyer ${ }^{\mathrm{II}}$ \\ ${ }^{I}$ Associate Professor, Department of Anesthesiology and Laboratory of Experimental Anesthesia, UNICAMP, Sao Paulo, Brazil. \\ ${ }^{\text {II }}$ Biologist, Center for Experimental Medicine and Surgery, UNICAMP, Sao Paulo, Brazil.

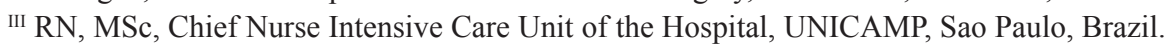

\begin{abstract}
Purpose: To compare the hemodynamic effects following a toxic dose of either agent after intravenous injection in swines, as might accidentally occur during regional anesthesia in humans. Methods: Large White pigs were anesthetized with thiopental, tracheal intubation was performed and mechanical ventilation was instituted. Hemodynamic variables were recorded with invasive pressure monitoring and pulmonary artery catheterization. After a 30-minute resting period, the animals were randomly divided into two groups in a double-blinded fashion and received a bolus intravenous injection of $4 \mathrm{mg} \cdot \mathrm{kg}^{-1}$ of either agent. Hemodynamic results were evaluated at rest and 1, 5, 10, 15, 20 and 30 minutes after intoxication. Results: Hemodynamic repressions of acute intoxication with levobupivacaine were more important and more prolonged than those of ropivacaína. Conclusion: In pigs, levobupivacaine was shown to be more toxic than ropivacaine when the same large doses are injected intravenously.
\end{abstract}

Key words: Poisoning. Hemodynamics. Anesthetics, Local. Swine.

\section{RESUMO}

Objetivo: Comparar as repercussões hemodinâmicas após a injeção endovenosa dos dois agentes em suínos simulando a intoxicação que pode ocorrer durante uma anestesia locorregional em humanos. Métodos: Suínos da raça Large-White foram anestesiados com tiopental, realizada intubação traqueal e instituída ventilação controlada mecânica. As variáveis hemodinâmicas foram medidas através de monitorização invasiva da pressão arterial e cateterização de artéria pulmonar. Após período de repouso de 30 minutos os animais foram aleatoriamente e em duplo-cego divididos em dois grupos e receberam por via endovenosa $4 \mathrm{mg}$. $\mathrm{kg}^{-1} \mathrm{de} u m$ ou outro agente. Os resultados hemodinâmicos foram avaliados em repouso e 1, 5, 10, 15, 20 e 30 minutos após a intoxicação. Resultados: As repercussões hemodinâmicas da intoxicação aguda com levobupivacaína foram mais importantes e mais prolongadas do que as com ropivacaína. Conclusão: Em suínos, a levobupivacaína foi mais tóxica do que a ropivacaína quando as mesmas grandes doses são injetadas por via endovenosa.

Descritores: Envenenamento. Hemodinâmica. Anestésicos Locais. Suínos.

${ }^{1}$ Research performed at Laboratory of Experimental Anesthesia, State University of Campinas (UNICAMP), Sao Paulo, Brazil.

\section{Introduction}

Regional anesthesia might require high doses of local anesthetic agents for surgery and there is always the potential risk for toxic reactions. Both the cardiovascular and central nervous systems are the primary target organs of local anesthetic toxicity in case of intravascular injection. Bupivacaine was one of the most widely used local anesthetics, due to its quality of anesthesia and prolonged duration of action ${ }^{1,2}$. Nevertheless, an Anesthesiology editorial on the severe cardiovascular effects of bupivacaine intoxication was published in $1979^{3}$ and since then research has focused on discovering new long-acting local anesthetics with lower toxicity. Although bupivacaine is synthesized in the form of its two dextrorotatory $\mathrm{R}(+)$ and levorotatory L(-) isomers ${ }^{4}$, evidences that the levorotatory isomers caused less toxicity was already known since $1972^{5,6}$. In the last decade the levorotatory isomers ropivacaine and levobupivacaine were developed as safer alternatives. Ropivacaine is the S(-) isomer of the propyl analogue of mepivacaine and bupivacaine, whereas levobupivacaine is the $\mathrm{S}(-)$ enantiomer of bupivacaine. Indeed, experimental and clinical data have demonstrated these two agents may be less toxic than bupivacaine ${ }^{7}$. In some animal models, the lethal dose of levobupivacaine was shown to be up to 1.6 times higher than that of the racemic mixture ${ }^{8}$ ! In humans, levobupivacaine would be less potent at producing negative inotropic effects and prolonging the PR and QT intervals of the ECG, typical of racemic mixture intoxication ${ }^{9}$. Despite having equal analgesic potency to racemic bupivacaina ${ }^{10}$ the drawback with this new agents would be its less intense motor block ${ }^{11}$, The aim of this study was to simulate an acute intoxication with either agent in pigs, as might accidentally occur during local and regional anesthesia with high doses of local anesthetics and to evaluate its hemodynamic repercussions. 


\section{Methods}

After approval from the Ethics Committee for Animal Experiments, 40 healthy Large White pigs (both sexes, body weight $20-27 \mathrm{~kg}$ ) underwent the following protocol and follow the Council for International Organization of Medical Sciences ethical code for animal experimentation and the principles of the Brazilian College on Animal Experimentation. The pigs were fasted the night before and had free access to water. The morning, the animals were weighed, an auricular vein was cannulated and anesthesia was induced with a $25 \mathrm{mg} . \mathrm{kg}^{-1} \mathrm{IV}$ dose of sodium thiopental ${ }^{12}$. The body surface area of the animal (BSA) was calculated using the formula ${ }^{13}: \mathrm{BSA}=\left(9 \times\right.$ weight in grams $\left.{ }^{2 / 3}\right)$ $\mathrm{x} 10^{-4} \mathrm{~m}^{2}$, introducing the result into the multiparametric Engstrom $\mathrm{AS} / 3$ monitor to calculate body index values. Intubation was performed and the animals were ventilated by a pneumatically driven ventilator using a partial re-breathing system and $\mathrm{CO}_{2}$ absorbent with tidal volume of $15 \mathrm{ml} . \mathrm{kg}^{-1}$ and respiratory rate to obtain $\mathrm{ETCO}_{2} 32-34 \mathrm{mmHg}$. Fresh oxygen flow was $11 . \mathrm{min}^{-1}$ and hemoglobin oxygen saturation was measured and kept above 97\%. ECG was also monitored. Anesthesia was maintained with an intravenous infusion of sodium thiopental $5 \mathrm{mg} \cdot \mathrm{kg}^{-1} \cdot \mathrm{h}$. In the medial left hind limb of the animal, dissection and cannulation of the femoral artery was performed for continuous arterial pressure measurement. A Swan-Ganz catheter was inserted into the femoral vein and hemodynamic measurements were made by the Datex Engstron AS/3 multiparametric monitor. Cardiac index (CI) mean arterial pressure (MAP), mean pulmonary artery pressure (MPAP), central venous pressure (CVP), pulmonary capillary wedge pressure (PCWP) stroke index (SI), systemic vascular resistance index (SVRI), pulmonary vascular resistance pulmonary index (PVRI), left ventricular stroke work index (LVSWI), right ventricular stroke work index (RVSWI) were measured. After a resting period of 30 minutes to ensure stabilization, baseline hemodynamic measurements were recorded $\left(\mathrm{T}_{0}\right)$. The animals were then randomly and in a double-blinded fashion divided in 2 groups: ropivacaine group (R) and levobupivacaine group (L). The animals received intravenously a toxic dose of $4 \mathrm{mg} \cdot \mathrm{kg}^{-1}$ of the local anesthetic ${ }^{14}$ during 30 seconds and the experimenter was blinded about the group. Additional hemodynamic measurements were recorded at 1, 5, 10, 15, 20 and 30 minutes after intoxication. At the end the animals were sacrificed while still under anesthesia by a $10 \mathrm{ml}$ intravenous injection of $19.1 \%$ potassium chloride solution. Then the double-blinded protocol was disclosed and data were statistically treated. For categorical variables the chi-square test was used and to compare the distribution of single numerical variables (measured at a single time point) the Student's t-test. To study changes in numerical variables measured at several time points, repeated-measures analysis of variance was performed (ANOVA). Furthermore, the Duncan test was used to compare the groups at each time point and the profile contrast test was applied to analyze the time course of each group. The significance level was set at $5 \%$, i.e., $\mathrm{p} \leq 0.05$.

\section{Results}

The following Table 1 shows the distribution by sex, mean and standard deviations of weight and body surface areas in both groups. There were no statistic differences.

TABLE 1

\begin{tabular}{ccc}
\hline GROUP & $\mathbf{L}$ & $\mathbf{R}$ \\
\hline female & $6(30 \%)$ & $9(45 \%)$ \\
male & $14(70 \%)$ & $11(55 \%)$ \\
weight \pm SD $(\mathrm{Kg})$ & $22,7 \pm 2,75$ & $21,96 \pm 2,08$ \\
$\mathrm{BSA} \pm \mathrm{SD}\left(\mathrm{m}^{2}\right)$ & $0,71 \pm 0,06$ & $0,69 \pm 0,05$ \\
\hline sex $\mathrm{p}=0,327 ;$ weight $\mathrm{p}=0,344 ; \mathrm{BSA} p=0,3$ &
\end{tabular}

There were no difference in any of the hemodynamic parameters measured at rest between groups.

Following intoxication, there was a reduction in cardiac index (Figure 1 and Table 2) in both groups but L was lower than $\mathrm{R}$ until the end $(\mathrm{p}<0.001)$ and did not return to values similar to $\mathrm{T}_{0}$ till the end while $R$ returned to resting values in $T_{10}(p<0.001)$.

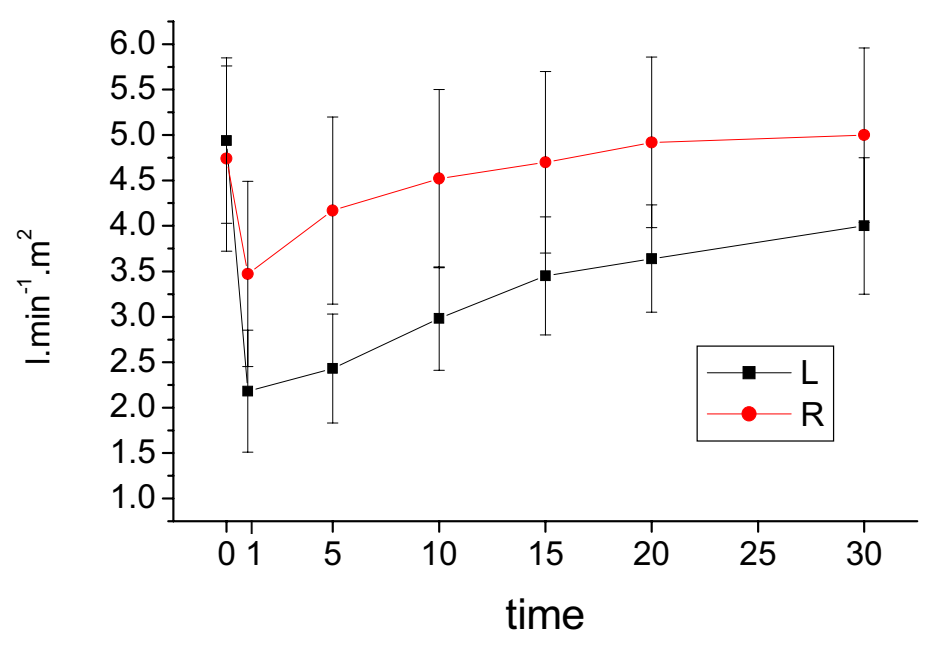

FIGURE 1 - Cardiac Index

TABLE 2 - Cardiac index $\pm \mathrm{SD}\left(1 \cdot \mathrm{min}^{-1} \cdot \mathrm{m}^{2}\right)$

\begin{tabular}{cccccccc}
\hline GROUP & $\mathrm{T}_{0}$ & $\mathrm{~T}_{1}$ & $\mathrm{~T}_{5}$ & $\mathrm{~T}_{10}$ & $\mathrm{~T}_{15}$ & $\mathrm{~T}_{20}$ & $\mathrm{~T}_{30}$ \\
$\mathbf{L}$ & $4.9 \pm 0.9$ & $2.2 \pm 0.7$ & $2.4 \pm 0.6$ & $3 \pm 0.6$ & $3.5 \pm 0.6$ & $3.6 \pm 0.6$ & $4 \pm 0.7$ \\
$\mathbf{R}$ & $4.7 \pm 1$ & $3.5 \pm 1$ & $4.2 \pm 1$ & $4.5 \pm 1$ & $4.7 \pm 1$ & $4.9 \pm 0.9$ & $5 \pm 1$ \\
\hline
\end{tabular}


Mean arterial pressure (Figure 2 and Table 3) decreased in both groups but $\mathrm{L}$ was lower than $\mathrm{R}$ from $\mathrm{T}_{1}$ to $\mathrm{T}_{5}$ and higher from $\mathrm{T}_{15}$ to $\mathrm{T}_{30}(\mathrm{p}<0.001)$. In $\mathrm{L}$ pressure was lower than $\mathrm{T}_{0}$ till $\mathrm{T}_{10}$ while in R only in $T_{1}(\mathrm{p}<0.001)$.

There was a significant and similar decrease in heart rate (Figure 3 and Table 4) in both groups. $\mathrm{L}$ did not reach $\mathrm{T}_{0}$ till the end but $\mathrm{R}$ did at $\mathrm{T}_{10}(\mathrm{p}<0.001)$. From $\mathrm{T}_{15}$ till $\mathrm{T}_{30} \mathrm{~L}$ had lower values than $\mathrm{R}$ $(\mathrm{p}<0.001)$.

Central venous pressure (Figure 4 and Table 5) increased significantly in both groups but more in $\mathrm{L}$ which was higher than $\mathrm{R}$ till the end $(p=0.012)$. L did not return to $T_{0}$ similar values but $\mathrm{R}$ did since $T_{5}(p<0.001)$.
TABLE 3 - Mean arterial pressure \pm SD $(\mathrm{mmHg})$

\begin{tabular}{cccccccc}
\hline GROUP & $\mathrm{T}_{0}$ & $\mathrm{~T}_{1}$ & $\mathrm{~T}_{5}$ & $\mathrm{~T}_{10}$ & $\mathrm{~T}_{15}$ & $\mathrm{~T}_{20}$ & $\mathrm{~T}_{30}$ \\
$\mathbf{L}$ & $94.8 \pm 15$ & $50.3 \pm 15.4$ & $66.1 \pm 20.3$ & $91.3 \pm 16.3$ & $100.3 \pm 12.7$ & $102.7 \pm 13.5$ & $103.7 \pm 15.9$ \\
$\mathbf{R}$ & $89.3 \pm 9.8$ & $77.7 \pm 2.5$ & $84.5 \pm 1.4$ & $87.9 \pm 9.6$ & $88 \pm 10.5$ & $87.3 \pm 9$ & $89.2 \pm 12.7$
\end{tabular}

TABLE 4 - Heart rate \pm SD (beats. $\min ^{-1}$ )

\begin{tabular}{cccccccc}
\hline GROUP & $\mathrm{T}_{0}$ & $\mathrm{~T}_{1}$ & $\mathrm{~T}_{5}$ & $\mathrm{~T}_{10}$ & $\mathrm{~T}_{15}$ & $\mathrm{~T}_{20}$ & $\mathrm{~T}_{30}$ \\
$\mathbf{L}$ & $131.9 \pm 17.4$ & $116.6 \pm 18.7$ & $122.5 \pm 20.2$ & $116.8 \pm 18.6$ & $110.1 \pm 15.1$ & $110.2 \pm 14.4$ & $115.3 \pm 16.7$ \\
$\mathbf{R}$ & $128.4 \pm 24.9$ & $118.3 \pm 25.3$ & $122.3 \pm 28$ & $123.6 \pm 28.9$ & $125.2 \pm 28.1$ & $126.2 \pm 28.3$ & $131.6 \pm 27.3$ \\
\hline
\end{tabular}

TABLE 5 - Central venous pressure $\pm \mathrm{SD}\left(\mathrm{cmH}_{2} \mathrm{O}\right)$

\begin{tabular}{cccccccc}
\hline GROUP & $\mathrm{T}_{0}$ & $\mathrm{~T}_{1}$ & $\mathrm{~T}_{5}$ & $\mathrm{~T}_{10}$ & $\mathrm{~T}_{15}$ & $\mathrm{~T}_{20}$ & $\mathrm{~T}_{30}$ \\
$\mathbf{L}$ & $9 \pm 2$ & $12 \pm 2.3$ & $11.2 \pm 2$ & $10.8 \pm 1.9$ & $10.4 \pm 1.9$ & $9.9 \pm 2.1$ & $9.9 \pm 1.9$ \\
$\mathbf{R}$ & $8.7 \pm 2.5$ & $9.6 \pm 2$ & $9.1 \pm 2.2$ & $8.6 \pm 2.2$ & $8.4 \pm 2$ & $8.5 \pm 2$ & $8.7 \pm 2.2$ \\
\hline
\end{tabular}

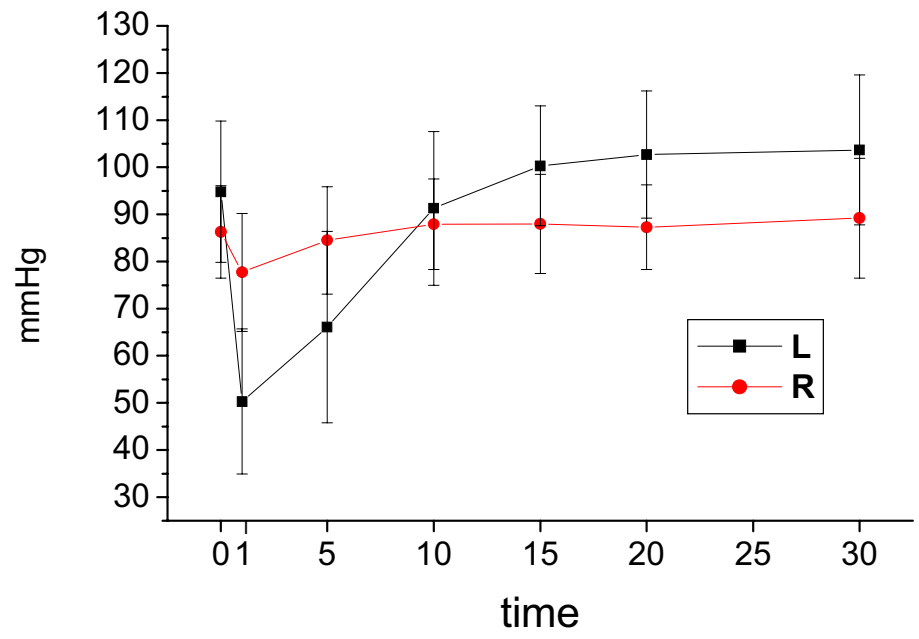

FIGURE 2 - Mean Arterial Pressure

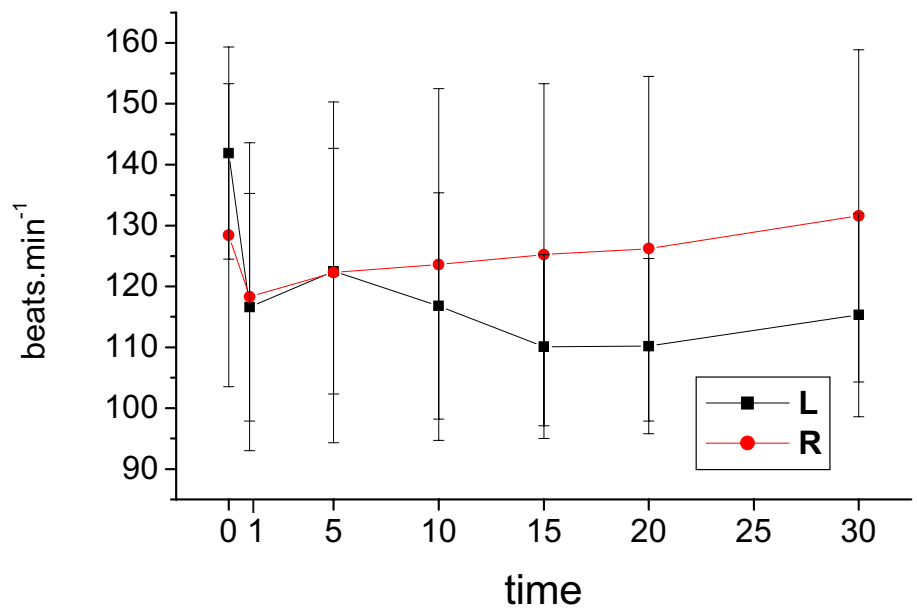

FIGURE 3 - Heart Rate

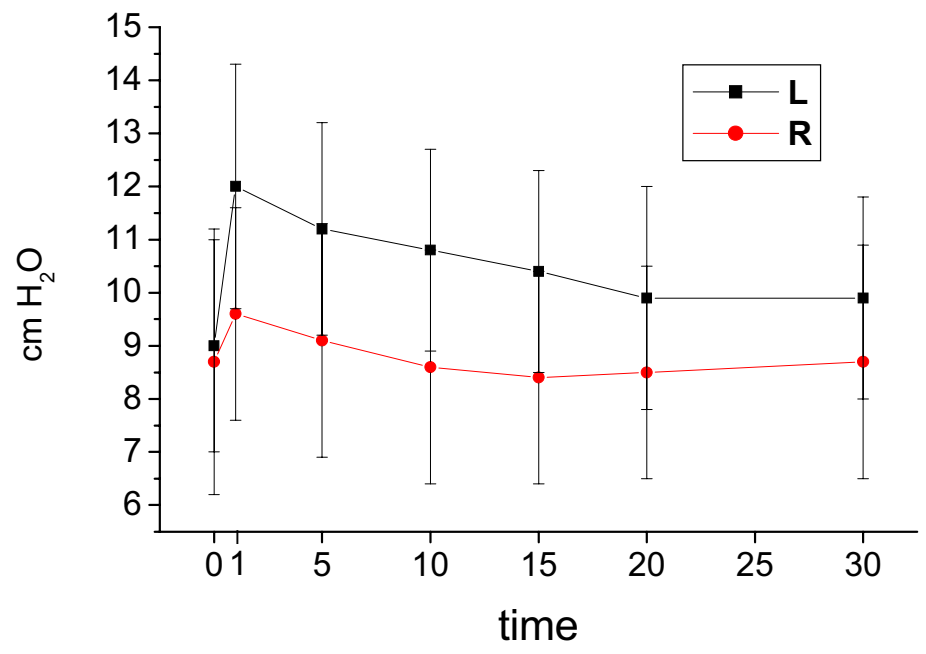

FIGURE 4 - Central Venous Pressure 
Mean pulmonary artery pressure (Figure 5 and Table 6) was higher in $\mathrm{L}$ than $\mathrm{R}$ from $\mathrm{T}_{5}$ till $\mathrm{T}_{30}(\mathrm{p}=0.021)$. There were no differences in times in both groups $(p=0.06)$.

Pulmonary capillary wedge pressure (Figure 6 and Table 7) showed increased values in both groups following intoxication but in $\mathrm{L}$ they were more important till $\mathrm{T}_{20}(\mathrm{p}=0.007)$. $\mathrm{L}$ did not return to resting values but $R$ did at $T_{10}$ $(p=0.042)$.

Stroke index (Figure 7 and Table 8 ) had a significant decline in both groups but in $\mathrm{L}$ these fall was more important till $\mathrm{T}_{20}(\mathrm{p}<0.001)$. L returned to resting values in $T_{20}$ while $R$ in $T_{5}$ $(\mathrm{p}<0.001)$.
TABLE 6 - Mean pulmonary artery pressure \pm SD (mmHg)

\begin{tabular}{cccccccc}
\hline GROUP & $\mathrm{T}_{0}$ & $\mathrm{~T}_{1}$ & $\mathrm{~T}_{5}$ & $\mathrm{~T}_{10}$ & $\mathrm{~T}_{15}$ & $\mathrm{~T}_{20}$ & $\mathrm{~T}_{30}$ \\
$\mathbf{L}$ & $19.1 \pm 3.9$ & $19.3 \pm 3.2$ & $19.6 \pm 3.5$ & $19.9 \pm 4.6$ & $19.7 \pm 4.4$ & $19.5 \pm 3.3$ & $19.5 \pm 3.2$ \\
$\mathbf{R}$ & $18.8 \pm 2.6$ & $18.6 \pm 3.3$ & $17.6 \pm 2.7$ & $16.8 \pm 2.7$ & $16.7 \pm 2.4$ & $17 \pm 2.5$ & $17.1 \pm 2.8$ \\
\hline
\end{tabular}

TABLE 7 - Pulmonary capillary wedge pressure \pm SD $(\mathrm{mmHg})$

\begin{tabular}{cccccccc}
\hline GROUP & $\mathrm{T}_{0}$ & $\mathrm{~T}_{1}$ & $\mathrm{~T}_{5}$ & $\mathrm{~T}_{10}$ & $\mathrm{~T}_{15}$ & $\mathrm{~T}_{20}$ & $\mathrm{~T}_{30}$ \\
$\mathbf{L}$ & $8.3 \pm 2.7$ & $11.7 \pm 2.9$ & $11.6 \pm 2.8$ & $10.4 \pm 2.4$ & $9.8 \pm 2.1$ & $9.5 \pm 2.1$ & $9.6 \pm 2.2$ \\
$\mathbf{R}$ & $7.5 \pm 2.1$ & $9.6 \pm 2.5$ & $8.6 \pm 2.4$ & $8.1 \pm 2.2$ & $7.9 \pm 2.2$ & $7.8 \pm 1.9$ & $8.2 \pm 2.8$ \\
\hline
\end{tabular}

TABLE 8 - Stroke index \pm SD $\left(\mathrm{ml} \cdot \mathrm{bat}^{-1} \cdot \mathrm{m}^{2}\right)$

\begin{tabular}{cccccccc}
\hline GROUP & $\mathrm{T}_{0}$ & $\mathrm{~T}_{1}$ & $\mathrm{~T}_{5}$ & $\mathrm{~T}_{10}$ & $\mathrm{~T}_{15}$ & $\mathrm{~T}_{20}$ & $\mathrm{~T}_{30}$ \\
$\mathbf{L}$ & $34.2 \pm 5$ & $18.2 \pm 5.7$ & $19.4 \pm 5.5$ & $24.4 \pm 6.5$ & $29.8 \pm 6.6$ & $31.9 \pm 5.9$ & $34.4 \pm 5$ \\
$\mathbf{R}$ & $36.6 \pm 5.9$ & $29 \pm 5.9$ & $34.2 \pm 7.1$ & $36.9 \pm 7.1$ & $37.7 \pm 6.7$ & $39.1 \pm 6.2$ & $38.2 \pm 6.5$ \\
\hline
\end{tabular}

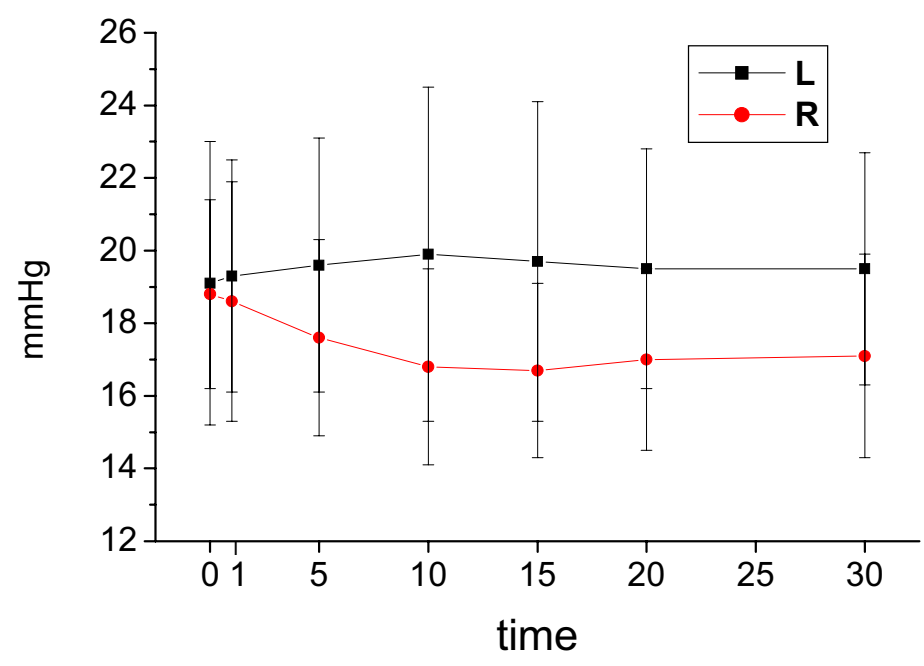

FIGURE 5 - Mean Pulmonary Artery Pressure

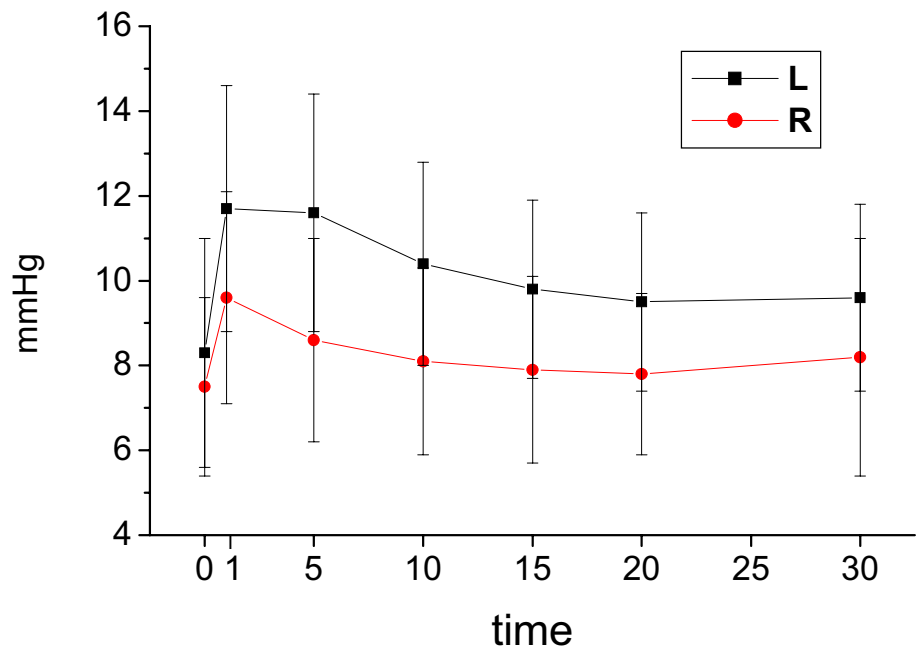

FIGURE 6 - Pulmonary Capillary Wedge Pressure

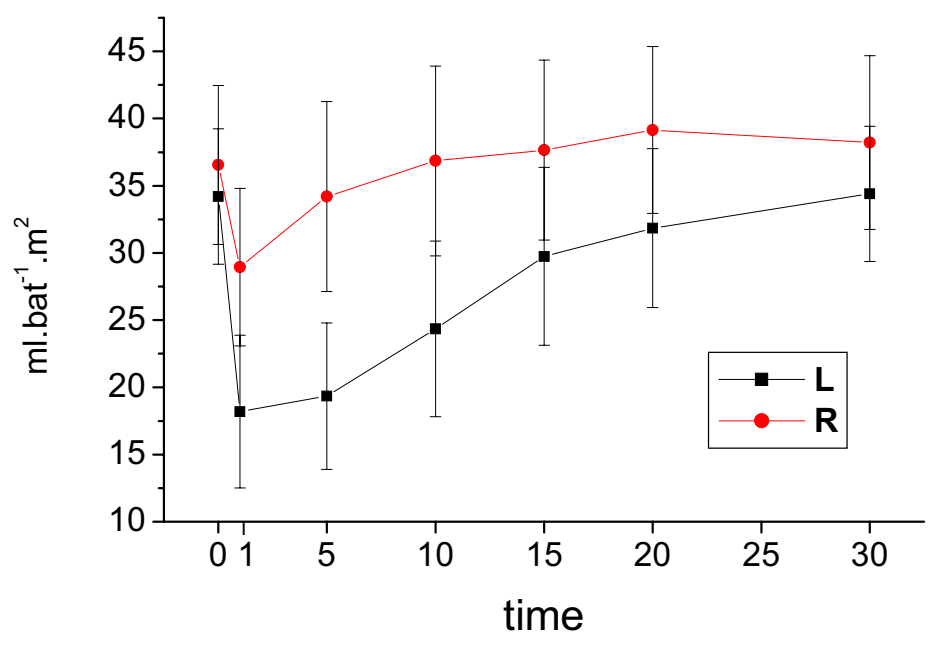

FIGURE 7 - Stroke Index 
In L systemic vascular resistance index (Figure 8 and Table 9) had a fall in $T_{1}$ but from $T_{10}$ till the end was greater than $\mathrm{T}_{0}$, $\mathrm{R}$ had an increase from $\mathrm{T}_{1}$ to $\mathrm{T}_{10}(\mathrm{p}<0.001)$. $\mathrm{L}$ was greater than $\mathrm{R}$ from $\mathrm{T}_{10}$ to $\mathrm{T}_{30}$ $(\mathrm{p}<0.001)$.

In $\mathrm{L}$ pulmonary vascular resistance index (Figure 9 and Table 10) showed higher values than resting in $\mathrm{T}_{1}, \mathrm{~T}_{5}$ and $\mathrm{T}_{20}(\mathrm{p}<0.001)$ while in $\mathrm{R}$ only in $\mathrm{T}_{1}$. L was greater than $\mathrm{R}$ from $\mathrm{T}_{5}$ to $\mathrm{T}_{30}(\mathrm{p}=0.013)$.

Left ventricular stroke work index (Figure 10 and Table 11) decreased after intoxication in both groups, however the fall was greater in $\mathrm{L}$ until $\mathrm{T}_{10}(\mathrm{p}<0.001)$. Values returned to similar to resting at $\mathrm{T}_{20}$ in $\mathrm{L}_{\text {and }} \mathrm{T}_{5}$ in $\mathrm{R}(\mathrm{p}<0.001)$.
TABLE 9 - Systemic vascular resistance index $\pm \mathrm{SD}\left(\right.$ dynes. $\left.\mathrm{sec}^{-1} \cdot \mathrm{cm}^{5} \cdot \mathrm{m}^{-2}\right)$

$\begin{array}{llllllll}\text { GROUP } & \mathrm{T}_{0} & \mathrm{~T}_{1} & \mathrm{~T}_{5} & \mathrm{~T}_{10} & \mathrm{~T}_{15} & \mathrm{~T}_{20} & \mathrm{~T}_{30}\end{array}$

L $\quad 1626 \pm 326.91409 \pm 314.81776 \pm 485.8 \quad 2199 \pm 409 \quad 2146 \pm 398.6 \quad 2106 \pm 402.8 \quad 1945 \pm 399$

R $\quad 1356 \pm 283.2 \quad 1644 \pm 418 \quad 1491 \pm 267.21448 \pm 292.51396 \pm 284.7 \quad 1309 \pm 238.7 \quad 1320 \pm 273.5$

TABLE 10 - Pulmonary vascular resistance index $\pm \mathrm{SD}\left(\right.$ dynes. $\left.\mathrm{sec}^{-1} \cdot \mathrm{cm}^{5} \cdot \mathrm{m}^{-2}\right)$

\begin{tabular}{llllllll}
\hline GROUP & $\mathrm{T}_{0}$ & $\mathrm{~T}_{1}$ & $\mathrm{~T}_{5}$ & $\mathrm{~T}_{10}$ & $\mathrm{~T}_{15}$ & $\mathrm{~T}_{20}$ & $\mathrm{~T}_{30}$
\end{tabular}

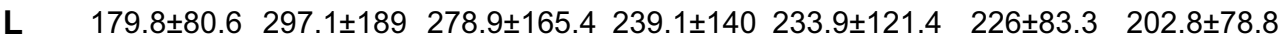

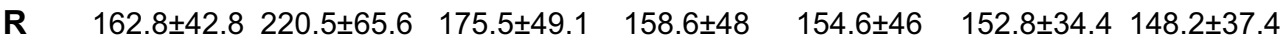

TABLE 11 - Left ventricular stroke work index $\pm \mathrm{SD}\left(\mathrm{g} \cdot \mathrm{min}^{-1} \cdot \mathrm{m}^{2}\right)$

\begin{tabular}{cccccccc}
\hline GROUP & $\mathrm{T}_{0}$ & $\mathrm{~T}_{1}$ & $\mathrm{~T}_{5}$ & $\mathrm{~T}_{10}$ & $\mathrm{~T}_{15}$ & $\mathrm{~T}_{20}$ & $\mathrm{~T}_{30}$ \\
$\mathbf{L}$ & $46 \pm 11.1$ & $10.2 \pm 6.3$ & $15.2 \pm 7.6$ & $28.6 \pm 10.7$ & $38 \pm 10.4$ & $41.6 \pm 11$ & $44.5 \pm 11.8$ \\
$\mathbf{R}$ & $39.4 \pm 9.6$ & $27 \pm 8.7$ & $36.1 \pm 12$ & $40.6 \pm 11.4$ & $41.6 \pm 11.4$ & $42.7 \pm 10$ & $42.4 \pm 11$ \\
\hline
\end{tabular}

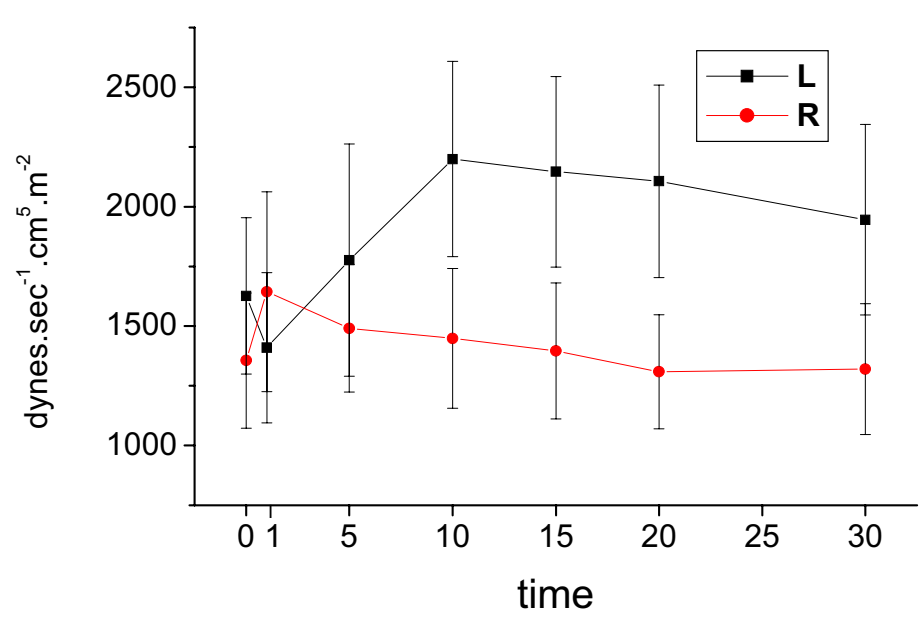

FIGURE 8 - Systemic Vascular Resistance Index

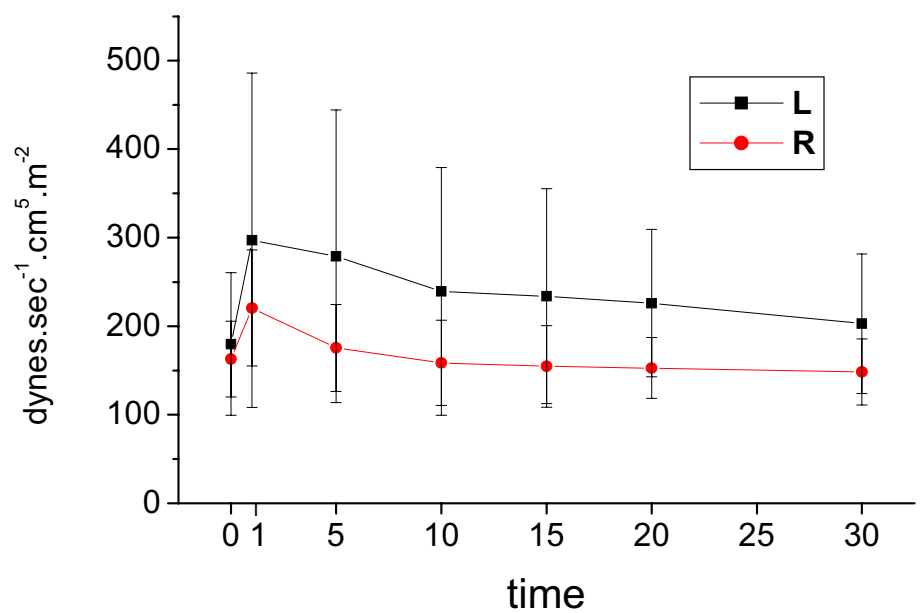

FIGURE 9 - Pulmonary Vascular Resistance Index

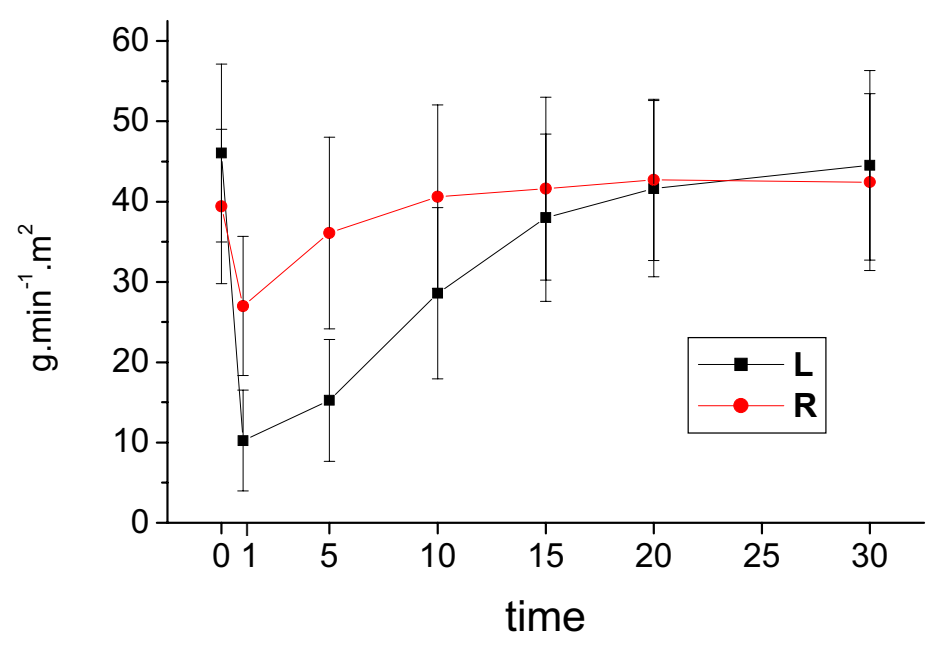

FIGURE 10 - Left Ventricular Stroke Work Index 
Right ventricular stroke work index (Figure 11 and Table 12) fall in both groups, but this was more important in $\mathrm{L}$ until $\mathrm{T}_{10}$ $(p=0.03)$. Values returned to to resting at $\mathrm{T}_{20}$ in $\mathrm{L}$ and $\mathrm{T}_{5}$ in $\mathrm{R}$ $(\mathrm{p}<0.001)$.
TABLE 12 - Right ventricular stroke work index \pm SD $\left(\mathrm{g} \cdot \mathrm{min}^{-1} \cdot \mathrm{m}^{2}\right)$

\begin{tabular}{cccccccc}
\hline GROUP & $\mathrm{T}_{0}$ & $\mathrm{~T}_{1}$ & $\mathrm{~T}_{5}$ & $\mathrm{~T}_{10}$ & $\mathrm{~T}_{15}$ & $\mathrm{~T}_{20}$ & $\mathrm{~T}_{30}$ \\
$\mathbf{L}$ & $4.6 \pm 1.7$ & $1.8 \pm 0.8$ & $2.2 \pm 0.8$ & $2.8 \pm 1.2$ & $3.8 \pm 1.7$ & $4.3 \pm 1.4$ & $4.4 \pm 1.5$ \\
$\mathbf{R}$ & $4.1 \pm 1.4$ & $3.6 \pm 1.2$ & $3.9 \pm 1.2$ & $4.1 \pm 1.2$ & $4.2 \pm 1.2$ & $4.5 \pm 1.2$ & $4.5 \pm 1.5$ \\
\hline
\end{tabular}

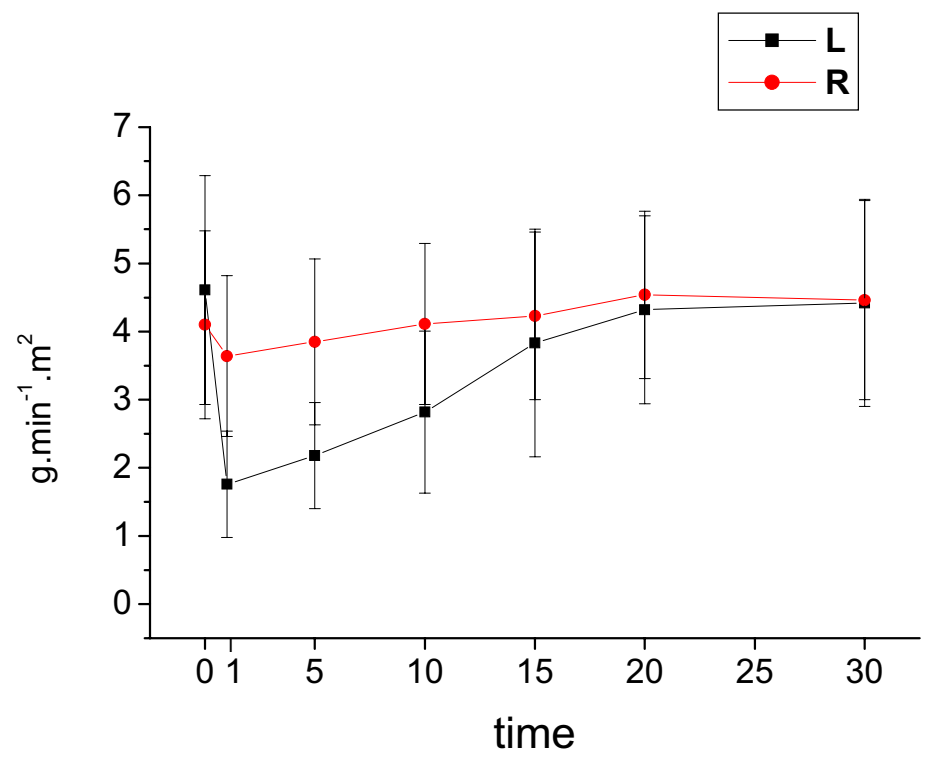

FIGURE 11 - Right Ventricular Stroke Work Index

\section{Discussion}

Cardiac toxicity of local anesthetics is attributed to a blockade of $\mathrm{Na}^{+}$in the heart leading to a prolonged conduction time with widening of QRS complexes, prolongation of PR interval, AV block and arrythmias ${ }^{15}$. These drugs cause cardiac toxicity as well by altering mitochondrial metabolism in cardiac cells and thus alter inotropism ${ }^{16}$. The $\mathrm{S}(-)$ isomer may be less cardiotoxic due to its lower affinity for cardiac $\mathrm{Na}^{+}$channels in comparison to the $\mathrm{R}(+)$ isomer as demonstrated in guinea pigs ${ }^{17}$ and ropivacaine would be less potent than levobupivacaine to block them ${ }^{18}$. Overall hemodynamic variables events seen with both drugs were similar but quantitative differences were found, with ropivacaine changes were less important and turned over more quickly to the starting values. Our results demonstrated that levobupivacaine had greater hemodynamic repercussions on a swine model of acute intoxication simulating what may occur after accidental intravenous injections of local anesthetics during local and regional anesthesia. Evidence of toxicity with the same doses was shown in the significantly more important decrease in cardiac index mean arterial pressure, heart rate and left ventricular stroke work index. However, further studies must be encouraged since Polley et al. ${ }^{19}$ found the drugs equipotent, Parpaglioni et al. ${ }^{20}$ levobupivacaine more potent, Liisanantti et al. ${ }^{21}$ ropivacaine more potent and different potencies could justify different results with the same doses. Accidental injections of high doses of local anesthetics and toxic reactions during local and regional anesthesia have decreased in the last 30 years, falling from 0.2 to $0.01 \%$. Peripheral nerve blocks still account for the majority of these cases $(7.5 \text { per } 10.000)^{22}$. Such considerations should intensify new efforts to discover drugs and techniques that enable to achieve a significantly low morbidity and mortality rate, protecting patients from the undesirable and unpredictable effects of local and regional anesthesia techniques with high doses of local anesthetics.

\section{Conclusion}

In pigs, levobupivacaine was shown to cause more important hemodynamic repercussions than ropivacaine when the same large doses are injected intravenously.

\section{References}

1. Groban L, Deal DD, Vernon JC, James RL, Butterworth J. Cardiac resuscitation after incremental overdosage with lidocaine, bupivacaine, levobupivacaine and ropivacaine in anesthetized dogs. Anesth Analg. 2001;92:37-43.

2. Chang DH-T, Ladd LA, Copeland S, Iglesias MA, Plummer JL, Mather LE. Direct cardiac effects of intracoronary bupivacaine, levobupivaciane and ropivacaine in the sheep. Br J Pharmacol. 2001;132:649-58.

3. Albright GA. Cardiac arrest following regional anesthesia with etidocaine or bupivacaine. Anesthesiology. 1979;51:285-7.

4. Ohmura S, Kawada M. Ohta T Yamamoto K, Kobayashi T. Systemic toxicity and resuscitation in bupivacaína, levobupivacaína or ropivacaine-infused rats. Anesth Analg. 2001;93:743-8.

5. Åberg G. Toxicological and local anesthetic effects of optically active isomers of two local anesthetic compounds. Acta Pharmacol Toxicol. 1972;31:273-86.

6. Luduena FP, Bogado EF, Tullar BF. Optical isomers of mepivacaine and bupivacaine. Arch Int Pharmacodyn. 1972;200:359-69.

7. Groban L. Central nervous system and cardiac effects from long-acting amide local anesthetic toxicity in the intact animal model. Reg Anesth Pain Med. 2003;28:3-11.

8. Foster RH, Markham A. Levobupivacaine. A review of its pharmacology and use as a local anesthetic. Drugs. 2000;59:551-79.

9. Bardsley H, Gristwood R, Baker H, Watson N, Nimmo W. A comparison of the cardiovascular effects of levobupivacaine and rac-bupivacaine following intravenous administration to healthy volunteers. Br Clin Pharmacol. 1998;46:245-9.

10. Lyons G, Columb M, Wilson RC, Johnson RV. Extradural pain relief in labour:potencies of levobupivacaine and racemic bupivacaine. Br J Anaesth. 1998;81:899-901.

11. Héctor JL, Columb MO. The relative motor blocking potencies of bupivacaine and levobupivacaine in labour. Anesth Analg. 2003;97:1509-13. 
12. Smith AC, Ehler WJ, Swindle MMl. Anesthesia and analgesia in swine. In: Kohn DF, Wixson SK, White WJ, Benson JG. Anesthesia and analgesia in laboratory animals. 1ed. New York: Academic Press; 1997. p.313-6.

13. Ettinger SJ. Textbook of veterinary internal medicine. vol.1. 1ed. Philadelphia: WB Saunders Co.; 1975.

14. Lefrant JY, Muller L, de La Coussaye JE, Lalourcey L, Ripart J, Peray PA, Mazoit X, Dauzat M, Sassine A, Eledjam JJ. Hemodynamic and cardiac electrophysiologic effects of lidocaine-bupivacaine mixture in anesthetized and ventilated piglets. Anesthesiology. 2003;98:96-103.

15. Clarkson CW, Hondeghem LM. Mechanism for bupivacaine depression of cardiac conduction: fast block of sodium channels during the action potential with slow recovery from block during diastole. Anesthesiology. 1985;62:396-405.

16. Butherworth JF, Brownlown RC, Leith JP, Prielipp RC, Cole LR. Bupivacaine inhibits cyclic 3.5 adenosine monophosphate production. A possible contribution factor to cardiovascular toxicity. Anesthesiology. 1993;79:88-95.
17. Valenzuela C, Snyders DJ, Bennett PB, Tamargo J, Hondeghem LM. Stereoselective block of cardiac sodium channels by bupivacaine in guinea pig ventricular myocytes. Circulation. 1995;92:3014-24.

18. Nau C, Strichartz GR. Drug chirality in anesthesia. Anesthesiology. 2002;97:497-502.

19. Polley LS, Columb MO, Naughton NN, Wagner DS, van de Ven CJ, Goralski KH. Relative analgesic potencies of levobupivacaine and ropivacaine for epidural analgesia in labor. Anesthesiology. 2003;99:1354-8. 20. Parpaglioni R, Frigo MG, Lemma A, Sebastiani M, Barbati G, Celleno D. Minimum local anaesthetic dose (MLAD) of intrathecal levobupivacaine and ropivacaine for caesarean section. Anaesthesia. 2006;61:110-5.

21. Liisanantti O, Luukkonen J, Rosenberg PH. High-dose bupivacaine, levobupivacaine and ropivacaine in axillary brachial plexus block. Acta Anaesthesiol Scand. 2004;48:601-6.

22. Cox B, Durieux ME, Marcus MA. Toxicity of local anesthetics. Best Pract Res Clin Anaesthesiol. 2003;17:111-36.

Conflict of interest: none Financial source: none

\section{Correspondence:}

Dr. Artur Udelsmann

Av. Prof. Atílio Martini, 213

13083-830 Campinas - SP Brazil

Phone / Fax: (55 19)3521-9560

audelsmann@yahoo.com.br

Received: January 20, 2009

Review: March 18, 2009

Accepted: April 15, 2009

\section{How to cite this article}

Udelsmann A, Silva WA, Moraes AC, Dreyer E. Hemodynamic effects of ropivacaine and levobupivacaine intravenous injection in swines. Acta Cir Bras. [serial on the Internet] 2009 July-Aug;24(4). Available from URL: http://www.scielo.br/acb 